\title{
Exploring the effect of the model of metacognitive instruction on the listening performance of EFL learners
}

Fahim, Mansoor

English Department, Science and Research Branch, Islamic Azad University, Tehran, Iran (dr.manfahim@yahoo.com)

Fakhri Alamdari, Ebrahim $\bowtie$

English Department, Science and Research Branch, Islamic Azad University, Tehran, Iran (fakhri.iau.ac@gmail.com)



Received: 24 January 2014

Revised: 20 February 2014

Available Online: 16 March 2014 DOI: $10.5861 /$ ijrsll.2014.700

\section{Abstract}

This study sought to explore the effect of two different models of metacognitive instruction on the listening performance of EFL learners in Iran. The participants were 90 intermediate EFL listeners in three groups, ranging from 20 to 26 years of age. The participants in experimental group one $(n=30)$ went through a ten-week intervention program that involved the linear instruction of ten metacognitive strategies, with its focus on planning, monitoring, and evaluation. The participants in experimental group two $(n=30)$, who were trained through Metacognitive Pedagogical Sequence for ten weeks, went through an intervention program that engaged them in a sequence of tasks to help them develop metacognitive awareness of the processes underlying L2 listening through dialogic interactions. The participants in the control group $(n=30)$, who went through a conventional listening instruction program, were taught by the same teacher and listened to the same materials without any guided attention to process. An actual test of language proficiency and a listening comprehension test were also used to collect data and to track changes in listening performance of learners after the intervention. The results of the study showed that metacognitive instruction led to a considerable variance in the overall listening performance of learners. The results also revealed that the model of metacognitive instruction and the manner through which metacognitive strategies were orchestrated led to a difference in the listening performance of EFL learners in this study.

Keywords: listening; metacognitive instruction; dialogic interactions; metacognitive pedagogical sequence 


\section{Exploring the effect of the model of metacognitive instruction on the listening performance of EFL learners}

\section{Introduction}

Listening comprehension is a crucial language skill that second and foreign language learners need to develop (Vandergrift, 2007). Listening, as the most frequently used language skill in the classroom (Morley, 1991; Vogely, 1995), assists language learners in receiving and interacting with language input and paves the way for the emergence of other language skills (Vandergrift \& Goh, 2012). Listening, as the "primary means of L2 acquisition" (Rost, 2002, p. 103), can also play a critical role in both the acquisition of a second language and the development of communicative competence in that language (Dunkel, 1991; Feyten, 1991; Krashen, 1981). Despite the vital role of listening, it has remained to be the least understood and the least researched skill in language learning, and it is often overlooked by foreign and second language teachers (Field, 2008). Listening comprehension is also regarded as a big challenge and a great source of anxiety for EFL learners (Arnold, 2000; Graham, 2006), which may lead to frustration in learners, and cause them to have a poor performance in the classroom. This could be attributed to the fact that L2 learners are rarely taught how to listen effectively (Berne, 2004; LeLoup \& Pontiero, 2007; Mendelsohn, 2006).

Another reason, according to Vandergrift and Goh (2012), is "the lack of guidance on how learners can self-direct and evaluate their efforts to improve their listening" (p. 5). They further assert that "language learners need to be supported and to understand the listening processes they are using" (p. 5). One effective way to help listeners with the complexity of listening comprehension is through "metacognitive instruction" (Goh, 2008). Through this process-based approach, as Mendelsohn (1998) maintains, instructors will have ample opportunities to equip learners with effective listening strategies, and teach them how to listen more effectively by making them aware of the mental processes that are involved in the process of listening.

Although there are a great number of research studies investigating the effect of metacognitive instruction on listening comprehension in both ESL and EFL contexts, the results have been largely inconclusive due to their flawed methodologies, their various intervention programs, sample size, and the contexts in which the studies were implemented. Thus these constraints call the need for more systematic research in the field in order to come up with more satisfactorily generalizable results. Furthermore, a quick look at the majority of textbooks dealing with listening in Iranian context indicates that language learning strategies are being instructed in Iran through pre-listening, listening, and post-listening activities. The first section, pre-listening phase, introduces new words in listening input and involves learners to see and read the questions before listening, which is per se insufficient. Pre-listening is followed by listening to the speech and responding to listening questions at the same time. Finally, students, along with the teachers' aides, examine their responses at the post-listening stage.

Despite the fact that teachers implement listening support during listening activities in the classroom, teachers still target listening product rather than listening process. As a result, there is a need for greater emphasis on how to listen and even how to engage learners directly in improving their listening comprehension through metacognitive strategy instruction as well as dialogic interactions so that learners can manage their own learning. Moreover, there is a dearth of socioculturally-informed studies exploring the effect of metacognitive instruction through dialogic interactions on the listening performance of EFL learners in Iran. Therefore, there is an urgent need to investigate language-learning strategies with regard to sociocultural perspective and metacognitive instruction through dialogic interactions. To this end, the focus of this study was to investigate the effect of metacognitive instruction and the effect the model of instruction can have on the listening performance of EFL learners in Iran. 


\section{Theoretical background}

\subsection{The importance of process-based approach}

Most L2 listening research, as Vandergrift (2007) maintains, has investigated either the product of listening by examining how listening condition can affect the overall comprehension, or sought to explore the cognitive processes employed by listeners while listening. While a relatively small body of L2 listening research has informed teaching techniques, much of the focus remains on the product of listening (Vandergrift, 2007). Instruction in listening has often been associated with testing, with its focus on the product of listening (Vandergrift, 2004), when the listener is still incapable of keeping up with the speech rate, which can often create a high level of anxiety (Goh, 2008), and affect attention capacity (Arnold, 2000). While focusing on product can give the teacher the chance to verify comprehension, the answer reveals nothing about the process; i.e., how students arrived at comprehension (Vandergrift, 2004).

A process-based approach can help learners learn how to listen, and guide them through the stages that seem to characterize real-life listening (Goh, 2002; Vandergrift, 2003). In the same vein, Vandergrift (2004) maintains that through a process-based approach, teachers can help learners learn how to comprehend short, authentic texts on topics related to their level and interests, and become more aware of how they can use what they already know to fill gaps in their understanding. Goh (2008) also promoted a process-based approach to listening instruction, in order to "demystify the skills" (p. 192), involved in listening comprehension. She referred to this type of process-based listening instruction as metacognitive instruction in listening, which is informed by the theory of metacognition that is now regarded as an indispensable part of human learning.

\subsection{Metacognitive instruction in listening}

The concept of "metacognition" has been described as "one's knowledge concerning one's own cognitive processes or anything related to them" (Flavel, 1976, p. 232), or as Wenden (1998) defined it, it refers to the learners "knowledge about learning" (p. 516). Metacognition, as Schraw (1998, p. 114) put it, comprises two main categories: knowledge of cognition and regulation of cognition. Knowledge of cognition involves what individuals know about their own mental processing and incorporates declarative, procedural and conditional awareness; whereas, regulation of cognition refers to all the actions the learners take so as to control their own learning and involves skills in planning, monitoring, and evaluation. Flavell (1979) deconstructed metacognitive knowledge into three types of knowledge including person, task, and strategy knowledge. Commenting on the significance of these three types of knowledge in learning, Goh and Taib (2006) maintain that any development in these three aspects of metacognitive knowledge will enable learners to evaluate themselves and help them select appropriate strategies in order to improve their listening performance. Metacognitive instruction, as described by Vandergrift and Goh (2012), refers to:

\section{Pedagogical procedures that enable learners to increase awareness of listening process by developing richer metacognitive knowledge about themselves as listeners, the nature and demands of listening, and strategies for listening. Learners also learn how to plan, monitor, and evaluate their comprehension efforts and the progress of their overall listening development ( $\mathrm{p}$. 97).}

Metacognitive instruction and its effectiveness in enhancing learners' listening comprehension ability have recently begun to be explored. A quick look at the findings of research on metacognitive instruction, as Goh (2010) maintains, indicates that metacognitive instruction in listening can be beneficial to learners in at least three ways, First, it improves affect in listening, helping learners to be more confident, more motivated and less anxious. Second, it increases learners' knowledge about the listening process and about themselves as second language listeners. Third, it has a positive effect on listening performance and strategy use for facilitating comprehension. She further argues that the purpose of metacognitive instruction in listening is to help learners 
Fahim, M. \& Fakhri Alamdari, E.

develop greater awareness about factors that influence their own listening and learning processes and learn strategies from their teachers and fellow-learners for self-directing these processes.

According to the findings of these studies, some scholars such as Vandergrift (2004) and Goh (2008) began to discuss the rationale for integrating metacognitive instruction into teaching listening comprehension based on the assumption that metacognitive instruction can potentially promote learners.' awareness of their listening and learning processes and develop their ability to use appropriate strategies in various contexts (Goh, 2008), although the mixed findings of the empirical studies on the efficacy of metacognitive instruction on listening performance have challenged the accuracy of this assumption.

\subsection{Models of metacognitive instruction}

Research holds evidence that metacognitive development can not only occur naturally through implicit socialization with experts, but it can also be enhanced through explicit intervention and scaffolded learning experiences in the classroom (Veenman et al., 2006). Research has also demonstrated that learners can benefit from an approach where strategies are taught in an integrated fashion (Vandergrift, 2004). Guiding listeners through the process as a whole as part of regular listening activities can help learners improve overall as listeners (Goh, 2002; Vandergrift, 2004). In the same line, Vandergrift (2004) asserts that metacognitive instruction is more effective in improving $L 2$ listening performance once it is embedded with a normal classroom listening activities than separately, which makes it abstract and less meaningful to the learners. Endorsing Vandergrift's comment, Veenman et al. (2006) also maintain that all metacognitive strategy training programs ought to be embedded in the subject matter to ensure connectivity.

There are a number of models proposed by various scholars for teaching learning strategies in both first and second language contexts (see Anderson, 2002; Chamot \& O'Malley, 1994; Chamot et al., 1999; Cohen, 1998; Vandergrift, 2004; Vandergrift \& Goh, 2012). These instructional models, as Chamot (2004) maintains, have three main features in common. First of all, they all endorse the fact that it is crucial to develop learners' metacognitive understanding of the value of learning strategies, and propose that this can be facilitated through teacher demonstration and modeling. Secondly, they all emphasize the importance of providing learners with multiple practice opportunities with strategies so that they can use them autonomously in and out of classroom context. Last but not least, all these models advocate the fact that learners should be able to evaluate how well a strategy has worked, to choose strategies for a task, and to actively transfer strategies to new tasks. Some of these metacognitive instruction models are briefly presented below.

One of the earliest metacognitive strategy training models developed by Chamot and O'Malley (1994) is known as CALLA. This model helps teachers integrate language, content, and learning strategies in a carefully planned lesson. Within this model, the learners' prior knowledge and their habit of evaluation of their own learning seem to be the major principles. According to Chamot and O'Malley (1994), the CALLA can be presented to learners in five sequential phases which are: preparation, presentation, practice, evaluation, and expansion, respectively. Chamot et al. (1999) also devised an updated, recursive, metacognitive instructional model of CALLA, which is based on the four metacognitive processes of planning, monitoring, evaluating, and problem-solving. The model, which is by no means linear, makes the learners flash back to a prior stage at any time to refine and improve their comprehension process. The model includes six instructional stages, which can be implemented through preparation, presentation, practice, self-evaluation, expansion, and assessment phases, respectively.

Endorsing the notion that understanding and controlling cognitive processes is one of the most crucial skills that learners need to develop, Anderson (2002) proposed a model based on which teachers should teach metacognitive strategies to help learners plan, control, and evaluate their learning in the classroom. In Anderson's model, metacognitive strategy training is divided into five primary components that are preparing and planning, deciding when to use particular strategies, monitoring strategy use, learning how to orchestrate various strategies, 
Exploring the effect of the model of metacognitive instruction on the listening performance of EFL learners

and evaluating strategy use.

Vandergrift (2004) proposed a metacognitive cycle to help learners integrate the use of strategies while listening. This model of metacognitive instruction, with its focus on improving listening comprehension through a process-based approach, encourages learners to actively create and check predictions, establish and address gaps in their understanding, and monitor and reflect on their performance. At specific stages in a lesson sequence, learners are encouraged to use strategies to regulate their comprehension and achieve successful comprehension. The model also provides learners with plenty of listening practice and can be flexibly used across different proficiency levels (Vandergrift 2004). The cycle involves five stages through which the listener progresses linearly. The stages are: the planning or predicting stage, the first verification stage, the second verification stage, the final verification stage, and the reflection stage.

In a recent attempt to help learners integrate the use of strategies while listening. Vandergrift and Goh (2012) proposed a model called Metacognitive Pedagogical Sequence, which encourages the use of dialogic interactions in negotiating metacognitive strategies. This proposed framework, which is informed by sociocultural perspectives of learning, integrates two aspects of learning: "learning as an individual cognitive enterprise and learning as a social enterprise" (Vandergrift and Goh, 2012, p. 93). Within this framework, dialogic interactions and activities learners participate in contribute to the overall learning of each individual in the interaction. The model can further provide learners with opportunities to enrich individual learning through peer dialog and cooperation. The Metacognitive Pedagogical Sequence involves the instruction of metacognitive strategies in five phases every session: Pre-listening - planning/predicting stage; First listen- first verification stage; Second listen- second verification stage; Third listen- final verification stage; Reflection \& goal-setting stage.

\subsection{Empirical investigations on metacognitive instruction}

One of the earliest strategic interventions, focusing on the effect of cognitive and metacognitive strategy training on L2 listening, was conducted by O'Malley (1987). The participants were 75 learners, divided into three groups: a metacognitive, a cognitive, and a control group. Although O'Malley's results fell short of statistical significance, they were in fact very informative and inspiring for future research. O'Malley and Chamot (1990) also conducted a study, in which a group of intermediate ESL learners received instruction in metacognitive, cognitive, and socio-affective strategies for academic listening. Results showed that the experimental group outperformed the control group in each of the daily tests, and the metacognitive group outperformed the cognitive one in three out of the four tests.

Vandergrift (1996) conducted a structured interview to examine the strategies used by core French students at different course levels. Based on the data he gathered, he concluded that three categories of strategies could be distinguished: cognitive, metacognitive, and socio affective. Students reported more cognitive strategies than the other categories. As the course level increased, the total number of strategies reported increased too. The same pattern was observed for metacognitive category. Females reported to have used more metacognitive strategies compared to males. Thompson and Rubin (1996) also carried out a longitudinal study, investigating the effect of process-based cognitive and metacognitive strategy training on the listening performance of university students learning Russian. The results demonstrated that the learners in the experimental group who received strategy instruction in listening to video-recorded texts improved significantly over their peers in the control group who had received no instruction. With regard to instruction in listening to audio-recorded texts, the control group also showed improvement, although the result fell short of statistical significance.

Goh (1997) examined Chinese students' metacognitive knowledge in L2 listening comprehension by asking them to keep a diary about their listening. The analysis of the diaries demonstrated that the students reported extensively on all three types of metacognitive knowledge. In another attempt to investigate the strategies used by learners, Vandergrift (1997) investigated the strategies used by novice and intermediate level of French students. He found that novice learners relied heavily on elaboration, transfer, and inferencing; whereas, 
Fahim, M. \& Fakhri Alamdari, E.

intermediate level learners used twice as many metacognitive strategies as the novice-level learners.

In another study, Vandergrift (2003) compared the listening comprehension strategies of more- and less-skilled Canadian seventh-grade students of French. Students listened to several French texts and were asked to think aloud during the process. The more skilled listeners used more metacognitive strategies, especially comprehension monitoring, than did their less skilled peers. In addition, more skilled listeners engaged in questioning for clarification, whereas the less skilled used more translation. Goh and Taib (2006) also conducted a study in which young Singaporean learners reported increased confidence and deeper awareness of L2 listening and they perceived improvements in listening ability. Learners' perceptions were corroborated by a comparison of pretest and posttest scores, with less skilled listeners making the greatest gains.

Graham and Macaro (2008) also conducted a longitudinal study that explored the effects of strategy instruction on the listening performance and self-efficacy of 68 lower-intermediate learners of French in England. Result revealed that the program improved listening proficiency and learners' confidence about listening. Another interesting strategic intervention was undertaken by Cross (2009). In this study, both the experimental $(n=7)$ and the comparison $(n=8)$ groups were exposed to a repetitive instructional methodology which cycled through the metacognitive processes of planning, monitoring, and evaluating, but the experimental groups also received explicit cognitive strategy training in addition to listening practice. The results demonstrated that both groups made statistically significant gains on the post-test, but there was no significant difference between the two groups.

Vandergrift and Tafaghodtari (2010) also used the pedagogical cycle to measure the comprehension performance of two groups of high-beginner/lower intermediate French learners; one group received metacognitive instruction, but the other group did not receive any guidance. The analysis of pretest and posttest listening comprehension scores showed that the experimental group significantly outperformed the control group. In another small-scale study on the effect of metacognitive instruction on listeners' comprehension, cross (2011a) conducted a study in which twenty adult, Japanese, advanced level EFL learners participated in a task sequence, or 'pedagogical cycle', of predicting, monitoring, problem identification, and evaluating in each of five listening lessons aimed at promoting their comprehension of television news items. The results indicated that three of four less-skilled listeners made notable gains across the five lessons, whereas only one of four more-skilled listeners improved.

There are also a few socioculturally-informed studies investigating the effect of metacognitive instruction and dialogic interactions on the listening performance of EFL learners. Cross (2009), for instance, investigated the development of metacognition in advanced Japanese learners and demonstrated how these listeners used collaborative dialogue to develop greater awareness of the metacognitive processes involved in listening. In another study, Cross (2010) explored metacognitive awareness in second language listening on six pairs of advanced Japanese, EFL learners, and concluded that through dialogue, learners could afford and exploit opportunities to enhance their metacognitive awareness of L2 listening. Cross (2011b) also conducted a small-scale study involving six pairs of Japanese EFL learners. The pairs completed dialogic recalls pertaining to their use of strategies to comprehend news videotexts. The results revealed that dialogic recalls can be used as a tool for classroom-based listening strategies research.

Studies discussed above and several others (e.g., Baleghizadeh \& Rahimi, 2011; Bozorgian, 2012, 2014; Carrier, 2003; Goh, 2002; Goh \& Hu, 2013; Goh \&Yusnita, 2006; Liu \& Goh, 2006; Mareschal, 2007; O’Bryan \& Hegelheimer, 2009; Rahimi \& Katal, 2012; Zeng, 2012) have also shown that listening comprehension could be improved through metacognitive instruction in the classroom. Although these empirical studies, investigating the impact of metacognitive instruction on listening comprehension have been very promising, they are not devoid of methodological constraints due to the challenges inherent in classroom-based, action research (Dörnyei, 2007). Thus, the present study made an attempt to make a meager contribution to the field by exploring the effect of metacognitive instruction on the listening performance of EFL learners. To this end, the 
Exploring the effect of the model of metacognitive instruction on the listening performance of EFL learners

following research questions were formulated:

1. Does metacognitive instruction have any effect on the listening performance of EFL learners?

2. Does the model of metacognitive instruction have any effect on the listening performance of EFL learners?

\section{Method}

\subsection{Participants}

A total number of 90 intermediate EFL learners, majoring in English Translation and Literature at two Iranian universities (Mazandaran \& IAU), participated in this study. The sample, screened through an actual test of language proficiency, was chosen out of 210 available junior EFL male/female learners, ranging from 20 to 26 years of age. Those learners whose scores on the language proficiency test fell within \pm 1 standard deviation of the mean score were recognized as the eligible participants for this study. Then, based on simple random sampling method, the researchers randomly assigned the learners to two experimental (EG1 = 30; EG2 = 30 ) and a control $(\mathrm{CG}=30)$ group prior to the implementation of the intervention programs. All the participants were given informed consent forms and were clarified regarding the nature and purpose of the study.

\subsection{Instruments}

Two instruments were used in this study: (a) A language proficiency test, and (b) A listening comprehension test. The first instrument was an actual test of language proficiency (TOEFL), extensively used by ETS in 2003.The test was administered not only to homogenize the participants in terms of their language proficiency, but also to be used as a criterion to estimate the validity of listening test developed by the researchers in this study.

The second instrument, used to measure the learners' listening comprehension performance, was a 30-item listening comprehension test, developed for the purpose of this study. The tests and the audio materials were based on Summit's Complete Assessment Package (Saslow \& Ascher, 2006). The test, which was used as both pre and post-tests, addressed such fundamental listening comprehension skills as main ideas, inference, and specific details in two formats familiar to students: multiple choice and True / False questions. A pilot study was conducted on a similar group of 30 learners before the pre-test administration to estimate the reliability and validity of the listening test. The Cronbach's alpha reliability of the test at the piloting stage was calculated to be 0.80 . The test validity was also determined by the correlation coefficient between the test of language proficiency and the listening comprehension test at the piloting stage, which turned out to be 0.74 .

\subsection{Experimental group one treatment}

The participants in the experimental group one (EG1) attended a ten-week intervention program, which involved the linear instruction of ten metacognitive strategies, allowing the participants to learn one metacognitive strategy at a time. The intervention program was informed by Graham and Macaro (2008), and Thompson and Rubin (1996) to help learners develop their listening performance. The participants attended the intervention program once a week, each lasting for 90 minutes. They listened to a different oral text, covering a variety of such daily topics as conversations, lectures, and interviews every session.

The lesson plan for the experimental group one comprised four stages for every session. Stage one focused on presenting and simplifying the definition of a metacognitive strategy and tried to describe it in terms of its function in a practical sense through some relevant examples. The second stage linked the metacognitive strategy to the topic of listening activities in the classroom, through which the researcher encouraged the learners to apply the metacognitive strategies during their listening activities in the classroom. In the third stage, the importance of 
each particular metacognitive strategy in developing listening performance was emphasized, and the learners were given ample time to practice it in the classroom. The last stage included a log for metacognitive instruction, which gave the researchers the chance to note the issues they encountered during the implementation of the intervention program every session.

Out of the ten weeks designed for the implementation of the lesson plan, the first week focused on planning. It elaborated on the definition and the concept of planning, and presented advanced organizers through some relevant explanations and examples. Then the researcher reiterated the importance of planning and advance organization in a real life context, and emphasized that learners should always set the scene before attending to the oral input. The researcher also emphasized the notion that attending to all the available information could help learners make predictions about what they might hear when dealing with listening input.

Week two dealt with the second subcategory of planning, which was directed attention. Here, the researcher advised the learners to concentrate on what they were listening to and guided them to ignore any irrelevant distracters while dealing with a listening task. The researcher also reiterated that the learners had to maintain attention through listening hard to what was being said. The learners were, then, advised to pay attention to the familiar words in order to associate ideas with the guesses they had already made, which helped them deal with the oral input before attending to it.

Week three focused on another subcategory of planning, which was selective attention. The researcher, here, guided the learners to focus on the topic and think of the key words in the listening input before listening to it. The learners were also advised to pay meticulous attention to the relationship between the interlocutors through the tone of voice addressing each other, too. The researcher, then, emphasized the crucial role of key words in dealing with the demand of the listening task, which helped the listeners deal with the oral input with less difficulty.

Week four dealt with the last subcategory of planning, which was learning management. This strategy obliged the learners to manage and adapt themselves to the new conditions as they listened. In this part, the researcher advised the learners to put everything aside and try to concentrate on what the speakers were saying. Indeed, the researcher guided the learners to frame their mind to comprehend the audio input with less difficulty, which gave the learners ample confidence in managing their learning and listening skill.

In week five, the researcher unpacked the concept of monitoring which covered three subcategories: comprehension, auditory, and double-checking monitoring, and focused on the definition of comprehension monitoring, in particular. The learners were, then, advised to translate any unfamiliar words to see if they sounded right in that particular context. They were also encouraged to put everything together, as understanding one thing could lead to the understanding of another. Then, the researcher had the learners listen to the audio text and advised them to monitor their comprehension as they approached the same listening topic anew.

In week six, the researcher presented the concept of auditory monitoring, which focused on how sounds made sense. Then, the researcher elaborated on the function of auditory monitoring, and advised the learners to use their L1 knowledge, and the sounds of words in order to associate them to other words they knew. The learners were also guided to find a sound link in their native language for further understanding.

Week seven dealt with double-check monitoring, which focused on checking comprehension during listening. Here, the researcher introduced the concept of double-check monitoring to the participants and suggested that they could benefit from it to check their understanding again during the phase of listening. The researcher also reminded the listeners that through double-check monitoring, they could increase the accuracy of their understanding in listening.

In week eight, the researcher demystified the concept of evaluation, which comprised three sub-categories: performance evaluation, strategy evaluation, and problem identification, and elaborated on the definition of 
Exploring the effect of the model of metacognitive instruction on the listening performance of EFL learners

performance evaluation. Then, in the light of listening activities in the classroom, the researcher reminded the learners of the power of evaluation, and emphasized that through performance evaluation, they could fill out where they lack understanding in listening.

In week nine, the concept of strategy evaluation was unpacked, and the researcher elaborated on a simplified definition of strategy evaluation in the light of listening activities in the classroom. Here, the researcher put further emphasis on the use of learning strategies before and during listening, and reiterated the fact that strategy evaluation in listening can help learners develop the use of listening strategies when the need arises.

In week ten, the last subcategory of evaluation, i.e., problem identification strategy, was presented to the learners. Through this strategy, the learners were recommended to identify where they lacked understanding, and they were also taught strategies on how to break their previous listening barriers. After implementing this intervention, the researcher administered the post-test to the participants in EG1 to explore the probable effect(s) of the intervention.

\subsection{Experimental group two treatment}

The participants in the experimental group two (EG2) also participated in a ten-week intervention program, which was informed by Vandergrift \& Goh's (2012) metacognitive pedagogical sequence, and encouraged the use of dialogic interactions in negotiating metacognitive strategies. The program was held once a week, 90 minutes each, through which the participants were exposed to a variety of such everyday topics as conversations, interviews, and lectures every session. The lesson plan for the experimental group two comprised five sequential steps for every session, which are as follows:

Stage one dealt with planning and predicting. Having administering the pre-test to the participants in EG2, the researcher started the intervention program by elaborating on the concept of language learning strategies. Various types of language learning strategies were briefly explained to the participants. Then the researcher focused on metacognitive strategies, in particular, and tried to clarify the ways students could benefit from the cycle of planning, monitoring, and evaluation to mitigate the challenges of the listening task, and to cope with the listening task more successfully. Every session, the researcher gave a new listening task to the participants based on which they were requested to brainstorm the kinds of information they might hear, as well as any related vocabulary, and write their predictions in the listening guide sheet (see Appendix 1). This prediction phase, with its focus on planning and predicting, was done in pairs or in small groups.

Stage two focused on the first verification. Having gone through the prediction stage, the participants listened to the text for the first time to measure and monitor their predictions about the topics and words used. They were also advised to work in pairs or groups to put a check mark beside the information they had predicted, compare their predictions with one another, discuss points of confusion, write any other new information if necessary, and identify the parts of the text that required careful attention during the second listening. Therefore, planning, monitoring, and selective attention were practiced and emphasized at this stage.

Stage three dealt with the second verification stage, which gave the chance to the participants to listen to the text for the second time in an attempt to figured out what they missed or misheard in the first time listening, resolve the points of difficulty raised after the first listening, make corrections, and note any new information down on their listening guide sheet. Then the researcher engaged the learners in a class discussion through which they could confirm their understanding of the text and negotiate how they had successfully managed to go through the process of comprehension. This stage, which helped the learners consider their listening problems through monitoring strategy, focused on monitoring, evaluation and problem solving, in particular.

Stage four involved the final verification, which gave the chance to the participants to listen to the text for the third time to focus not only on the information revealed to them through the class discussion, but also on the 
Fahim, M. \& Fakhri Alamdari, E.

information they had not been able to make sense of before. The metacognitive processes practiced at this stage were selective attention, monitoring, and problem solving.

Stage five, or the goal-setting stage, focused on the learners' reflection of the metacognitive strategies used during the listening tasks. Here, the researcher encouraged the participants to work in pairs to utter their personal reflections on the listening process, and further note any strategies they would use in the following session to deal with the listening task more readily. The metacognitive processes emphasized at this stage were evaluation and planning. Having gone through the ten-week metacognitive instruction program, the participants in EG2 were also invited to take the post-test of listening.

\subsection{Control group treatment}

The participants in the control group (CG) were taught listening conventionally. They were allowed to listen to the same oral texts the same number of times, but it was devoid of any guided attention to the process. They were not given the chance to discuss, predict, monitor their comprehension, or negotiate strategies with their peers in the classroom, either. They were only engaged in a discussion after the third listen in order to ensure about their comprehension of the text. Furthermore, there was no discussion of strategy use for the participants in the control group, and they were not engaged in any formal reflection on their approach to listening during the intervention program, either.

\section{Results}

The research questions in this study tried to explore the effect of metacognitive instruction on the listening performance of EFL learners, and also sought to investigate as to whether there were any significant differences among the three groups in terms of their listening performance as a result of having been exposed to two different models of metacognitive instruction. To this end, a one-way between - group analysis of variance (one-way ANOVA) was run to compare the listening comprehension scores of the three groups in the pre-test of listening. The results of the descriptive statistics of overall scores of the three groups for pre-test of listening are presented in Table 1.

\section{Table 1}

Descriptive statistics of overall scores of the three groups for pre-test of listening

\begin{tabular}{lcccccc}
\hline & $N$ & Mean & SD & SEM & Min. & Max. \\
\hline Experimental Group 1 & 30 & 20.93 & 4.40 & .803 & 11.00 & 28.00 \\
Experimental Group 2 & 30 & 19.93 & 3.52 & .643 & 14.00 & 27.00 \\
Control Group & 30 & 22.23 & 4.60 & .841 & 11.00 & 29.00 \\
Total & 90 & 21.03 & 4.26 & .449 & 11.00 & 29.00 \\
\hline
\end{tabular}

Table 1 summarizes the results of the one-way ANOVA comparing the listening comprehension scores of the learners in the experimental (EG1 \& EG2) and control groups before the intervention. According to the results in Table 2, there was no statistically significant difference in mean scores between EG1 ( $\mathrm{M}=20.93 ; \mathrm{SD}=4.40)$, EG2 ( $M=19.93 ; \mathrm{SD}=3.52$ ), and the control ( $\mathrm{M}=22.23 ; \mathrm{SD}=4.60$ ) group before the intervention, i.e., the $\mathrm{P}$. value is more than $.05(.111>.05)$, suggesting that there was no statistically significant difference among the three groups in terms of their listening performance before the intervention.

Table 2

One-way ANOVA results comparing the three groups in pre-test of listening

\begin{tabular}{lccccc}
\hline & Sum of Squares & $d f$ & Mean Square & $F$ & Sig \\
\hline Between Groups & 79.80 & 2 & 39.900 & 2.25 & .111 \\
Within Groups & 1537.100 & 87 & 17.668 & & \\
Total & 1616.900 & 89 & & & \\
\hline
\end{tabular}


Exploring the effect of the model of metacognitive instruction on the listening performance of EFL learners

Considering the fact that the three groups were equal in terms of their listening performance, the data from the post-tests were used not only to compare the mean scores of the three groups in terms of their listening performance, but also to evaluate the effect of treatments on each group after the implementation of the interventions. To this end, due to the non-normality of the data set, a Kruskal-Wallis test, the nonparametric equivalent of one-way ANOVA, was used for the analyses of the post-tests (Larson-Hall, 2010), whose results are presented in Tables 3 and 4.

Table 3

Descriptive statistics of overall scores of the three groups for post-test of listening

\begin{tabular}{lcccccc}
\hline & $N$ & Mean & SD & SEM & Min. & Max. \\
\hline Experimental Group 1 & 30 & 25.33 & 3.06 & .559 & 21.00 & 30.00 \\
Experimental Group 2 & 30 & 27.83 & 1.80 & .328 & 24.00 & 30.00 \\
Control Group & 30 & 22.53 & 4.30 & .785 & 13.00 & 29.00 \\
Total & 90 & 25.23 & 3.86 & .406 & 13.00 & 30.00 \\
\hline
\end{tabular}

Table 4

Kruskal Wallis Test results comparing the three groups in post-test of listening

\begin{tabular}{lccccc}
\hline \multicolumn{1}{c}{ Groups } & $N$ & Mean Rank & Chi-square & $d f$ & Asymp. Sig. \\
\hline Experimental Group 1 & 30 & 44.12 & 27.815 & 2 & .000 \\
Experimental Group 2 & 30 & 63.85 & & & \\
Control Group & 30 & 28.53 & & & \\
Total & 90 & & & & \\
\hline
\end{tabular}

Table 3 summarizes the results of the Kruskal-Wallis test comparing the listening comprehension scores of the learners in the experimental (EG1 \& EG2) and control groups after the intervention. A quick look at the mean rank scores obtained from the post-tests (Table 4) demonstrates that the participants in the experimental groups (EG1 \& EG2) outperformed their peers in the control group (CG). In fact, the mean rank score obtained by EG2 (63.85) exceeded the mean score obtained by EG1 (44.12), which was, in turn, higher than the mean score belonging to CG (28.53). According to the overall results, as shown in Table 4, the Chi-square value (27.81) is more than the critical value of 5.99 for the df of 2 and the $\mathrm{p}$ value of .05 , suggesting that the differences in mean scores among the three groups, EG1 $(\mathrm{M}=25.33$; $\mathrm{SD}=3.06)$, EG2 ( $\mathrm{M}=27.83 ; \mathrm{SD}=1.82)$, and the CG ( $\mathrm{M}=$ 22.53; $\mathrm{SD}=4.30)$, are statistically significant after the intervention. The P. value of $.000(.000<.05)$ also implies that the intervention programs did lead to a great variance in the listening performance of learners in both experimental groups after the intervention.

Although the information presented in Table 4 is very revealing, it does not show exactly where the differences lie. Therefore, in order to respond to the second research question more accurately, the Kruskal-Wallis test was also used to compare the groups in pairs based on the rank scores obtained from their listening performance. Table 5 summarizes the results of the Kruskal-Wallis Test, comparing the ranks of the groups in pairs in the post-test of listening.

\section{Table 5}

Kruskal Wallis Test results comparing the ranks of the groups in pairs in the post-test of listening

\begin{tabular}{lccccc}
\hline \multicolumn{1}{c}{ Groups } & N Mean Rank & Sum of Ranks & $Z$ & Sig. \\
\hline Experimental Group 1 & 30 & 23.37 & 701.0 & -3.18 & .001 \\
Experimental Group 2 & 30 & 37.63 & 1129.0 & & \\
& & & & -2.56 & .010 \\
Experimental Group 1 & & 36.25 & 1087.5 & & \\
Control Group & 30 & 24.75 & 742.5 & & .000 \\
& & & & -5.00 & \\
Experimental Group 2 & & 41.72 & 1251.5 & & \\
Control Group & & 19.28 & 578.5 & & \\
Total & 90 & & & & \\
\hline
\end{tabular}


As can be seen in Table 5, there are three pairs, compared based on their ranks in the post-test of listening. In pair one; the comparison is between EG1 and EG2, with the mean ranks of 23.37 and 37.63, respectively. The results showed that there was a statistically significant difference between the two groups $(\mathrm{Z}=-3.18 ; \mathrm{P}=.001)$ in terms of their listening performance after the implementation of the intervention programs. This can further suggest that the learners in EG2 who experienced metacognitive instruction through dialogic interactions outperformed their peers in EG1, who went through the linear instruction of metacognitive strategies.

In pair two, there is a comparison between EG1 and CG, with the mean ranks of 36.25 and 24.75, respectively. The results also showed that there was a statistically significant difference between the two groups ( $\mathrm{Z}=-2.56 ; \mathrm{P}=.010$ ) in the post-test of listening, suggesting that the participants in the experimental group one, who went through the linear instruction of metacognitive strategies, outperformed their peers in the control group, who were taught listening conventionally without any attention to the process.

In pair three, the comparison is between EG2 and CG, with the mean ranks of 41.72 and 19.28, respectively. The results indicated that there was a statistically significant difference between the two groups $(Z=-5.00 ; P$ $=.000)$ in terms of their listening performance after the intervention. This result can also suggest that the learners in EG2 who experienced metacognitive instruction through dialogic interactions outperformed their peers in in the control group, who were taught listening conventionally without any attention to the process.

In a nutshell, the results of Mann-Whitney tests revealed a significant difference between each pair in each group in the post-test of listening. Therefore, both null hypotheses can safely be rejected, and it can be claimed that the model of instruction and the manner through which metacognitive strategies are orchestrated can lead to a variance in the learners' listening performance.

\section{Discussion}

Research into listening strategies in both ESL and EFL contexts has continued to grow in recent years (Goh, 2008; Vandergrift, 2004, 2007; Vandergrift \& Goh, 2012). There are also a great number of empirical studies that reflect the significance of metacognitive instruction in listening for language development ( see Baleghizadeh \& Rahimi, 2011; Bozorgian, 2012; Coskun, 2010; Cross, 2010; Goh \& Taib, 2006; Mareschal, 2007; O’Bryan \& Hegelheimer, 2009; Rahimi \& Katal, 2012; Vandergrift, 2002, 2003; Vandergrift \& Tafaghodtari, 2010; Zeng, 2012). Based on the results of these studies, it has been postulated that learners' metacognition, raised through metacognitive instruction, can directly affect the process and the outcome of their learning (Goh, 2008; Wenden, 1998), make them better at processing and storing information (Vandergrift, et al. 2006), help them better cope with difficulties during listening (Goh, 2002), and direct them to self-regulate their learning (Wenden, 1998). The findings of the present study indicated that metacognitive instruction through a process-based approach can be beneficial to EFL learners in developing their listening comprehension ability.

The results showed a significant difference between the control and the experimental groups in terms of their listening performance, which was achieved through the intervention programs in this study. The results also revealed that the model of metacognitive instruction and the manner through which metacognitive strategies were orchestrated led to a difference in the listening comprehension performance of learners. As in the case of this study, there was a significant difference between the two experimental groups in terms of their listening performance after the implementation of the intervention programs, suggesting that the learners in the experimental group two (EG2) who went through metacognitive pedagogical sequence and experienced metacognitive instruction through dialogic interactions outperformed their peers in the experimental group one (EG1) who went through the linear instruction of metacognitive strategies. This result might not have been achieved without the dialogic interactions of learners to verbalize metacognitive strategies within the metacognitive pedagogical sequence.

This finding also provides further empirical support for three other socioculturally-informed studies by 
Exploring the effect of the model of metacognitive instruction on the listening performance of EFL learners

Cross $(2009,2010,2011 \mathrm{~b})$, which investigated the effect of metacognitive instruction and dialogic interactions on the listening performance of EFL / ESL learners, and concluded that through collaborative dialog, learners could afford and exploit opportunities to enhance their listening comprehension performance and their metacognitive awareness of L2 listening.

Considering the effect of intervention programs through process-based approaches to listening, there are a great number of empirical studies with mixed findings about the impact of metacognitive instruction on listening performance of learners. The findings of this study are consistent with those of previous studies (e.g., Baleghizadeh \& Rahimi, 2011; Bolitho et al., 2003; Bozorgian, 2012, 2014; Coskun, 2010; Cross, 2010; Goh \& Taib, 2006; Mareschal, 2007; O’Bryan \& Hegelheimer, 2009; Rahimi \& Katal, 2012; Vandergrift, 2002, 2003; Vandergrift \& Tafaghodtari, 2010; Zeng, 2012), providing further empirical support for the positive effect of metacognitive instruction on listening comprehension, but none of the studies mentioned above sought to explore and compare the effect of two models of metacognitive instruction on the listening performance of ESL / EFL learners, nor did any of them try to investigate the effect of metacognitive instruction through dialogic interactions on the listening comprehension performance of learners within the metacognitive pedagogical sequence in the Iranian context. The results of this study are, however, inconsistent with those of other studies that found no immediate effect on enhancement of listening comprehension as a result of metacognitive instruction (e.g., O’Malley et al., 1985; O’Malley, 1987; Thompson \& Rubin, 1996; Ozeki, 2000; Chen \& Haung, 2011; Rahimi \& Katal, 2013). This lack of significance could be attributed to such factors as the length of instruction, the role of context, and the learners' proficiency in listening comprehension.

Regarding the length of the intervention program, some researchers (see Graham \& Macaro, 2008; Mareschal, 2007; Vandergrift \& Tafaghodtari, 2010; Veenman et al., 2006) have suggested that a prolonged metacognitive instruction program can yield more positive outcomes in enhancing learners' listening proficiency. Aligned with that notion, the results of this study also showed that the ten-week metacognitive instruction programs led to a considerable variance in listening performance of learners in both experimental groups. This can further imply that the length of the intervention program can be regarded as an effective factor in the implementation of any metacognitive instruction programs in both EFL and ESL contexts.

Considering the context as another crucial factor affecting any metacognitive instruction programs, the participants in this study were Persian intermediate learners learning English as a foreign language. Although research into metacognitive instruction has a long history in ESL contexts (e.g. Bacon, 1992; Cross, 2009, 2010; O’Malley et al., 1989; Mareschal, 2007; Murphy, 1985), it has recently gained recognition in EFL setting (e.g. Baleghizadeh \& Rahimi, 2011; Bozorgian, 2012, 2014; Chen \& Huang, 2011; Coskun, 2010; Rahimi \& Katal, 2012, 2013) with abundance of mixed results. The findings of the present study add further empirical support to the results of some studies in EFL context that found a positive effect of metacognitive instruction on the listening performance of learners (see Baleghizadeh \& Rahimi, 2011; Bozorgian, 2012, 2014; Coskun, 2010; Rahimi \& Katal, 2012). The results are, nevertheless, inconsistent with those of Ozeki (2000), Seo (2000), Chen \& Huang (2011), and Rahimi \& Katal (2013), which found a non-significant improvement in the learners' listening performance after the implementation of their metacognitive instruction programs. However, what makes this study conspicuously different with the previous studies in EFL context was the use of a socioculturally-informed intervention program, which involved the learners in the experimental group two to engage in dialogic interactions that led to a great enhancement in their listening comprehension performance.

Most of the research studies carried out with sociocultural perspective of learning in both ESL / EFL settings are related to teaching speaking and writing skills (Aljaafreh \& Lantolf, 1994; Barnard \& Campbell, 2005; Cotheral \& Cohen, 2003; Foster \& Ohta, 2005; Gibbons, 2003; Guerrero \& Villamil, 2000; Mccafferty, 2002; Ohta, 1995, as cited in Ghafar Samar \& Dehqan, 2013), and there is one socioculturally-informed study (see Ghafar Samar \& Dehqan, 2013) that has recently explored the effect of using sociocultural techniques on EFL learners' strategic reading repertoire in Iran. As far as it concerns listening, as Cross (2010) maintains, very few SCT-informed studies investigating the development of L2 learners' metacognitive awareness have been 
Fahim, M. \& Fakhri Alamdari, E.

conducted thus far. Therefore, research on language-learning strategies with its focus on sociocultural perspective and metacognitive instruction through dialogic interactions is in its embryonic stage in both ESL / EFL contexts. Thus, this study was one of the first attempts to have explored the effect of dialogic interaction in negotiating metacognitive strategies on the listening performance of EFL learners in Iran.

All in all, according to the results, it can be concluded that metacognitive instruction through the implementation of explicit intervention programs in the classroom (Veenma \& Spaans, 2005), the manner in which strategies are orchestrated while listening (Cross, 2009), the length of instruction (Mareschal, 2007; Vandergrift \& Tafaghodtari, 2010), and the context in which the research is conducted (Bozorgian, 2012; Coskun, 2010; Cross, 2009, 2010; Mareschal, 2007) can sensitize language learners to the process underlying listening (Vandergrift \& Tafaghodtari, 2010), and guide them on how to approach the task of listening more successfully (O’Bryan \& Hegelheimer, 2009).

\section{Conclusion, Future directions and implications}

This empirical study examined the efficacy of metacognitive instruction on the learners' listening comprehension in the EFL context. The results provide some empirical support for the notion that metacognitive instruction presented through a well-designed intervention program can be beneficial to learners and help them develop their listening proficiency. The findings of this study can provide some guidelines for both teachers and teacher educators on how to promote learners' metacognitive listening strategies through process-based approaches to listening. One important way to raise learners' metacognitive awareness is to incorporate the principles of process-based instruction in designing EFL instructional materials and activities. This is particularly important because most of the teaching materials and course books in EFL contexts do not adequately cover activities related to learning strategies. Thus, it is crucial to call for fundamental changes in the design of EFL syllabi and teaching materials. In doing so, teachers will have ample opportunities to make learners familiar with the concept of language learning strategies, which can help them have better insight about listening tasks and listening strategies, which may facilitate the listening process.

Teachers are also required to broaden their understanding of strategy-based instruction so as to be able equip their learners with knowledge of strategies to be used in different tasks inside and outside of the classroom contexts. The findings of this study can also remind teachers of the notion that there is a need for a shift in conventional listening instruction where the focus is on listening product rather than listening process. Therefore, teachers need to put greater emphasis on how to listen and even how to engage learners directly in improving their listening comprehension through metacognitive instruction so that they can manage and regulate their own learning. The results of this study can also inspire language learners to use more social and cooperative techniques in the context of language learning and practice collaborative learning, which necessitates the presence of peers who provide them with opportunities to correct themselves, and learn the strategic processes needed for the learning of new and difficult skills.

Dialogic interactions in sociocultural context, as Aljaafreh \& Lantolf (1994) put it, can also help learners move from other-regulation to self-regulation. This can further provide some empirical support for the notion that metacognitive instruction through dialogic interactions, along with a process-based approach, can be particularly helpful to guide and assist learners in developing their listening comprehension, and help them regulate their own learning. As in the case of this study, the results show that metacognitive instruction through both instructional models contributed significantly to the enhancement of the intermediate learners' listening comprehension. Like any other studies, the findings of this study cannot be generalized to all EFL contexts due to such constraints as the length and the model of instruction, the role of context, and the learners' proficiency in listening comprehension, which can all constrain the generalizability of the results. Thus, there is an urgent need for further research to examine the effectiveness of metacognitive instruction with more learners in various contexts, through longer intervention programs. and across different proficiency levels. Last but not least, there is also a need for more research to examine the effect of various instructional models on the listening 
Exploring the effect of the model of metacognitive instruction on the listening performance of EFL learners

performance of learners in various settings, as the comparative study of the effect of such models on the listening performance of learners is still rare in both ESL and EFL contexts. Thus, it is highly recommended to use different strategy instruction models to come to sound conclusions.

\section{References:}

Aljaafreh, A., \& Lantolf, J. P. (1994). Negative feedback as regulation and second language learning in the zone of proximal development. The Modern Language Journal, 78(4), 471-483. http://dx.doi.org/10.1111/j.1540-4781.1994.tb02064.x

Anderson, N. J. (2002). The role of metacognition in second language teaching and learning. ERIC Digest. Retrieved March 2013 from http://www.eric.ed.gov/PDFS/ED463659.pdf

Arnold, J. (2000). Seeing through listening comprehension anxiety. TESOL Quarterly, 34, 777-786. http://dx.doi.org/10.2307/3587791

Bacon, S. M. (1992). The relationship between gender, comprehension, processing strategies, and cognitive and affective response in foreign language listening. The Modern Language Journal, 76(2), 160-178. http://dx.doi.org/10.1111/j.1540-4781.1992.tb01096.x

Baleghizadeh, S., \& Rahimi, A. H. (2011). The relationship among listening performance, metacognitive strategy use and motivation from a self-determination theory perspective. Theory and Practice in Language Studies, 1, 61-67. http://dx.doi.org/10.4304/tpls.1.1.61-67

Berne, J. E. (2004). Listening comprehension strategies: A review of the literature. Foreign Language Annals, 4(37), 521-331. http://dx.doi.org/10.1111/j.1944-9720.2004.tb02419.x

Bolitho, R., Carter, R., Hughes, R., Ivanic, R., Masuhara, H., \& Tomlinson, B. (2003). Ten questions about language awareness. ELT Journal, 57(3), 251-260. http://dx.doi.org/10.1093/elt/57.3.251

Bozorgian, H. (2012). Metacognitive instruction does improve listening comprehension. ISRN Education, 1-6. http://dx.doi.org/10.5402/2012/734085

Bozorgian, H. (2014). The role of metacognition in the development of EFL learners' listening skill. International Journal of Listening, 28, 1-13.

Carrier, K. (2003). Improving high school English language students' second language listening through strategy instruction. Bilingual Research Journal, 27(3), 383-408. http://dx.doi.org/10.1080/15235882.2003.10162600

Chamot, A. U. (2004). Issues in language learning strategy research and teaching. Electronic Journal of Foreign Language Teaching, 1(1), 14-26.

Chamot, A. U., Barnhardt, S., El-Dinary, P., \& Robbins, J. (1999). The learning strategies handbook. White Plains, NY: Longman.

Chamot, A. U., \& O'Malley, J. M. (1994). The CALLA handbook: Implementing the cognitive academic language learning approach. White Plains, NY: Addison Wesley Longman.

Chen, C. C. \& Huang, C. T. (2011, October 28-28). Raising EFL college students' metacognitive awareness about listening. Paper presented at the NYS TESOL 41st Annual Conference, Melville, NY.

Cohen, A. D. (1998). Strategies in learning and using a second language. London: Longman.

Coşkun, A. (2010). The effect of metacognitive strategy training on the listening performance of beginner students. Research on Youth and Language, 4(1), 35-50.

Cross, J. (2009). Effects of listening strategy instruction on news videotext comprehension. Language Teaching Research, 13(2), 151-176. http://dx.doi.org/10.1177/1362168809103446

Cross, J. (2010). Raising L2 listeners' metacognitive awareness: A socio-cultural theory perspective. Language Awareness, 19(4), 281-297. http://dx.doi.org/10.1080/09658416.2010.519033

Cross, J. (2011a). Metacognitive instruction for helping less-skilled students. ELT Journal, 65(4), 408-416. http://dx.doi.org/10.1093/elt/ccq073

Cross, J. (2011b). Utilizing dialogic recalls to determine L2 listeners' strategy use. Innovation in Language Learning and Teaching, 5(1), 81-100. http://dx.doi.org/10.1080/17501229.2010.533776

Dörnyei, Z. (2007). Research methods in applied linguistics. Oxford: Oxford University Press. 
Fahim, M. \& Fakhri Alamdari, E.

Dunkel, P. (1991). Listening in the native and Second/Foreign language: Toward an integration of research and practice. TESOL Quarterly, 25, 431-457. http://dx.doi.org/10.2307/3586979

Feyten, C. M. (1991). The power of listening ability: An overlooked dimension in language acquisition. Modern Language Journal, 75, 173-180. http://dx.doi.org/10.1111/j.1540-4781.1991.tb05348.x

Field, J. (2008). Emergent and divergent: A view of second language listening research. System, 36(1), 2-9. http://dx.doi.org/10.1016/j.system.2008.01.001

Flavell, J. H. (1976). Metacognitive aspects of problem solving. In L. B. Resnick (Ed.), The nature of intelligence (pp. 231-236). Hillsdale, NJ: Erlbaum.

Flavell, J. H. (1979). Metacognition and cognitive monitoring: A new area of cognitive-developmental inquiry. American Psychologist, 34, 906-911. http://dx.doi.org/10.1037/0003-066X.34.10.906

Ghafar Samar, R., \& Dehqan, M. (2013). Sociocultural theory and reading comprehension: The scaffolding of readers in an EFL context. International Journal of Research Studies in Language Learning, 2(3), 67-80. http://dx.doi.org/10.5861/ijrsll.2012.183

Goh, C. (1997). Metacognitive awareness and second language listeners. ELT Journal, 51, 361-369. http://dx.doi.org/10.1093/elt/51.4.361

Goh, C. (2002). Learners' self-reports on comprehension and learning strategies for listening. Asian Journal of English Language Teaching, 12, 45-68.

Goh, C. (2008). Metacognitive instruction for second language listening development: Theory, practice and research implications. RELC Journal, 39(2), 188-213. http://dx.doi.org/10.1177/0033688208092184

Goh, C. (2010). Listening as process: Learning activities for self-appraisal and self-regulation. In N. Harwood, English language teaching materials (pp. 179-206). Cambridge: Cambridge University Press.

Goh, C., \& Hu, G. W. (2013). Exploring the relationship between metacognitive awareness and listening performance with questionnaire data. Language Awareness. http://dx.doi.org/10.1080/09658416.2013.769558

Goh, C., \& Taib, Y. (2006). Metacognitive instruction in listening for young students. ELT Journal, 60, $222-232$. http://dx.doi.org/10.1093/elt/ccl002

Goh, C., \& Yusnita, T. (2006). Metacognitive instruction in listening for young learners. ELT Journal, 60(3), 222-232. http://dx.doi.org/10.1093/elt/ccl002

Graham, S. (2006). Listening comprehension: The students' perspective. System: An International Journal of Educational Technology and Applied Linguistics, 34(2), 165-182. http://dx.doi.org/10.1016/j.system.2005.11.001

Graham, S., \& Macaro, E. (2008). Strategy instruction in listening for lower-intermediate students of French. Language Learning,, 58(4), 747-783. http://dx.doi.org/10.1111/j.1467-9922.2008.00478.x

Krashen, S. (1981). Second language acquisition and second language learning. Oxford: Pergamon Press.

Larson-Hall , J. (2010). A guide to doing statistics in second language research using SPSS. London: Routledge.

LeLoup, J. W., \& Ponterio, R. (2007). Listening: You've got to be carefully taught. Language Learning \& Technology, 11(1), 4-15.

Liu, X. L., \& Goh, C. (2006). Improving second language listening: Awareness and involvement. In T. S. C. Farrell (Ed.), Language teacher research in Asia (pp. 91-106). Alexandria, VA: TESOL.

Mareschal, C. (2007). Student perceptions of a self-regulatory approach to second language listening comprehension development. Unpublished doctoral dissertation, University of Ottawa, Ottawa, Ontario, Canada.

Mendelsohn, D. (1998). Teaching listening. Annual Review of Applied Linguistics, 18, 81-101. http://dx.doi.org/10.1017/S0267190500003494

Mendelsohn, D. (2006). Learning how to listen using learning strategies. In Us’o, Juan, \& Mart'inez, Flor (Eds.), Current trends in the development and teaching of the four language skills (pp.75-90). Walter de Gryuter GmbH \& CO. KG, D-10785. Berlin.

Morley, J. (1991). Listening comprehension in second/foreign language instruction. In M. Celce- Murcia (Ed.), Teaching English as a second or foreign language (pp. 81-106). New York: Newbury House.

Murphy, J. (1985). An investigation into the listening strategies of ESL college students. ERIC Document 
Exploring the effect of the model of metacognitive instruction on the listening performance of EFL learners

Reproduction Service No. ED278275 Retrieved from http://eric.ed.gov/PDFS/ED278275.pdf

O'Bryan, A., \& Hegelheimer, V. (2009). Using a mixed methods approach to explore strategies, metacognitive awareness and the effects of task design on listening development. Canadian Journal of Applied Linguistics, 12, 9-37.

O'Malley, J. M. (1987). The effects of training in the use of learning strategies on learning English as a second language. In A. Wenden \& J. Rubin (Eds.). Learner strategies in language learning (pp. 133-143). Cambridge: Prentice-Hall.

O'Malley, J. M., \& Chamot, A. U. (1990). Learning strategies in second language acquisition. Cambridge: Cambridge University Press. http://dx.doi.org/10.1017/CBO9781139524490

O’Malley, J. M., Chamot, A. U., \& Kupper, L. (1989). Listening comprehension strategies in second language acquisition. Applied Linguistics, 10(4), 418-437. http://dx.doi.org/10.1093/applin/10.4.418

O'Malley, J. M., Chamot, A. U., Stewer-Manzanare, G., Russo, R. P., \& Kupper, L. (1985). Learning strategy application with students of English as a second language. TESOL Quarterly, 19(3), 557-584. http://dx.doi.org/10.2307/3586278

Ozeki, N. (2000). Listening strategy instruction for female EFL college students in Japan. Unpublished doctoral dissertation, Indiana University of Pennsylvania, Pennsylvania, USA.

Rahimi, M., \& Katal, M. (2012). Metacognitive listening strategies awareness in learning English as a foreign language: A comparison between university and high-school students. Procedia: Social and Behavioral Sciences, 31, 82-89.

Rahimi, M., \& Katal, M. (2013). The impact of metacognitive instruction on EFL learners' listening comprehension and oral language proficiency. Journal of Teaching Language Skills, 5(2), 69-90.

Rost, M. (2002). Teaching and researching listening. London: Pearson Education.

Seo, K. (2002). The effects of visuals on listening comprehension: A study of Japanese learners' listening strategies. International Journal of Listening, 16, 57-81. http://dx.doi.org/10.1080/10904018.2002.10499049

Saslow, J., \& Ascher, A. (2006). Summit 1: Complete assessment package. New York: Pearson Education, Inc.

Schraw, G. (1998). Promoting general metacognitive awareness. Instructional Science, 26, 113-125. http://dx.doi.org/10.1023/A:1003044231033

Thompson, I., \& Rubin, J. (1996). Can strategy instruction improve listening comprehension? Foreign Language Annals, 29, 331-342. http://dx.doi.org/10.1111/j.1944-9720.1996.tb01246.x

Vandergrift, L. (1996). The listening comprehension strategies of core French high school students. Canadian Modern Language Review, 52, 200-223.

Vandergrift, L. (1997). The comprehension strategies of second language (French) students: A descriptive study. Foreign Language Annals, 30(3), 387-409. http://dx.doi.org/10.1111/j.1944-9720.1997.tb02362.x

Vandergrift, L. (2002). It was nice to see that our predictions were right: Developing metacognition in L2 listening comprehension. The Canadian Modern Language Review, 58, 555-575. http://dx.doi.org/10.3138/cmlr.58.4.555

Vandergrift, L. (2003). From prediction through reflection: Guiding students through the process of L2 listening. Canadian Modern Language Review, 59(3), 425-440. http://dx.doi.org/10.3138/cmlr.59.3.425

Vandergrift, L. (2004). Listening to learn or learning to listen? Annual Review of Applied Linguistics, 24, 3-25. http://dx.doi.org/10.1017/S0267190504000017

Vandergrift, L. (2007). Recent development in second and foreign language listening comprehension research. Language Teaching, 40, 191-210. http://dx.doi.org/10.1017/S0261444807004338

Vandergrift, L., \& Goh, C. (2012). Teaching and learning second language listening: Metacognition in action. New York: Rutledge.

Vandergrift, L., \& Tafaghodtari, H. M. (2010). Teaching L2 students how to listen does make a difference: An empirical study. Language Learning, 60(2), 470-497. http://dx.doi.org/10.1111/j.1467-9922.2009.00559.x

Veenman, M., \& Spaans, M. A. (2005). Relation between intellectual and metacognitive skills: Age and task differences. Learning and Individual Differences, 15(2), 159-176. 
Fahim, M. \& Fakhri Alamdari, E.

http://dx.doi.org/10.1016/j.lindif.2004.12.001

Vogely, A. (1995). Perceived strategy use during performance on three authentic listening comprehension tasks.

The Modern Language Journal, 79(1), 41-56. http://dx.doi.org/10.1111/j.1540-4781.1995.tb05414.x

Wenden, A. L. (1998). Metacognitive knowledge and language learning. Applied Linguistics, 19(4), 515-537.

http://dx.doi.org/10.1093/applin/19.4.515

Zeng, Y. (2012). Metacognition and self-regulated learning (SRL) for Chinese EFL listening development.

Unpublished doctoral dissertation, Nanyang Technological University, Singapore.

\section{Appendix}

Guide sheet for listening

Guide for Listening

A. Write down five main ideas that you think will be mentioned in the text.

1.

2

3.

4.

5 .

B. Discuss your predictions with a partner and then write down at least two more ideas that your partner included in his/her list of predictions and that you consider logical possibilities:

6.

7.

C. Listen to the text. Place a check mark beside the ideas that you and your partner predicted and that were in fact mentioned in the text, and write down any other ideas that you had not predicted but were mentioned.

8.

9.

10.

D. After verifying your predictions and discussing your listening results with your partner, listen to the text again to check your results and to resolve any discrepancies in comprehension between you and your partner. Add any further points and important details that you may not have understood during the first listen:

1.

2.

3.

4.

5.

E. Listen to the text a third time to verify comprehension after a class discussion of the content of the text or a reading of the text transcript.

\section{Reflections and Goal-Setting}

I was successful in anticipating ideas.

What surprised me?

What I will do next time: 